\title{
In vitro antimicrobial efficiency of a mouthwash containing triclosan/gantrez and sodium bicarbonate
}

\author{
Eficiência antimicrobiana in vitro de um \\ enxaguatório bucal contendo triclosan/gantrez \\ e bicarbonato de sódio
}

\author{
Juliana Rico Pires ${ }^{(a)}$ \\ Carlos Rossa Junior ${ }^{(b)}$ \\ Antonio Carlos Pizzolitto(c)
}

\begin{abstract}
(a) Graduate Student in Periodontology; (b)Adjunct Professor of Periodontology - School of Dentistry of Araraquara, São Paulo State University.
\end{abstract}

(c) Professor, Department of Clinical Analyses, School of Pharmaceutical Sciences of Araraquara, São Paulo State University.

\section{Corresponding author:}

Carlos Rossa Junior

Rua Humaitá, 1680, Centro

Araraquara - SP - Brazil

CEP: 14801-903

E-mail: crossajr@foar.unesp.br

Received for publication on Oct 11, 2006

Sent for alterations on Mar 16, 2007

Accepted for publication on May 14, 2007

\begin{abstract}
Several antiseptic substances have been used as adjuncts to routine mechanical procedures of oral hygiene, based on their antimicrobial effects. The objective of this study was to assess in vitro the antimicrobial efficiency of a mouthwash containing Triclosan/Gantrez and sodium bicarbonate in comparison to both positive and negative controls. Standard strain samples of Escherichia coli, Pseudomonas aeruginosa, Actinomyces viscosus and Bacillus subtilis were used. Samples of Streptococcus mutans and Gram-negative bacilli were collected from 20 volunteers (10 with a clinically healthy periodontium and 10 presenting biofilm-associated gingivitis). Evaluation of the antimicrobial activity was performed by determining the minimal inhibitory concentration (MIC). The results indicated that the test solution inhibited the growth of both Gram-negative and Gram-positive microorganisms from the volunteers' saliva as well as that of the standard strains at the MIC dilution of 1:20, whereas the MIC dilution of $0.12 \%$ chlorhexidine against the same bacteria was 1:80. Thus, even though the tested mouthrinse solution presented an in-vitro antimicrobial activity superior to that of a placebo, it was inferior to that of chlorhexidine.
\end{abstract}

Descriptors: Anti-bacterial agents; Triclosan; In vitro.

Resumo: Diversas substâncias antisépticas têm sido utilizadas como adjuntos aos procedimentos mecânicos rotineiros de higiene oral, com base em seus efeitos antimicrobianos. O objetivo deste estudo foi avaliar, in vitro, a eficiência antimicrobiana de um enxaguatório bucal contendo Triclosan/Gantrez e bicarbonato de sódio, em comparação a controles positivos e negativos. Linhagens padrão de Escherichia coli, Pseudomonas aeruginosa, Actinomyces viscosus e Bacillus subtilis foram utilizadas. Amostras de Streptococcus mutans e Bacilos Gram-negativos foram coletadas de 20 voluntários (10 com um periodonto clinicamente saudável e 10 com gengivite associada à presença de biofilme). A avaliação da atividade antimicrobiana foi realizada pela determinação da Concentração Inibitória Mínima (CIM). Os resultados mostraram que a solução teste inibiu o crescimento de microrganismos Gram-negativos e Gram-positivos da saliva dos voluntários, bem como das linhagens padrão na CIM de 1:20, enquanto que a CIM da diluição de clorexidina $0.12 \%$ contra as mesmas bactérias foi de 1:80. Desta forma, apesar de o enxaguatório bucal testado apresentar atividade antimicrobiana in vitro superior à do placebo, esta foi inferior à da Clorexidina.

Descritores: Agentes antimicrobianos; Triclosan; In vitro. 


\section{Introduction}

Mechanical control of dental biofilm has a somewhat limited success in part because it is regarded as time-consuming and technically difficult by most patients. This fact, coupled with an increase in the information available on the microbiology of periodontal diseases, has stimulated a great interest in developing topical antimicrobial agents to control dental biofilm. Mouthwashes have been particularly well accepted by patients due to their ease of use.

Among the chemotherapic agents used in mouthwashes, chlorhexidine usually is the "gold-standard" or positive control for comparison to other substances due to its proven efficiency. ${ }^{4,11}$ Recently, Triclosan - a low-toxicity, non-ionic phenolic derivative with a wide spectrum of antimicrobial activity - has been successfully incorporated into toothpastes, resulting in moderate but distinct positive effects on both the dental biofilm and marginal inflammation or gingivitis. ${ }^{9}, 10$

There is evidence indicating that the ingredients in the formula of triclosan-containing mouthwashes, including vehicle and other active substances, may influence its antimicrobial activity, and consequently its clinical efficiency. ${ }^{6}$ The use of copolymers to improve active agent delivery is well established. ${ }^{7}$ Methoxyethylene and maleic acid (Gantrez) are copolymers that have been proven to increase triclosan retention in the oral cavity, but the precise mechanism of this enhancement is still unknown. ${ }^{12,13}$ Some authors have reported that, when used in combination with Triclosan, Gantrez clearly enhances the uptake of this antibacterial agent by teeth and soft tissues. ${ }^{14}$

Rodrigues et al..$^{12}$ (1999) reported that the addition of Zinc Citrate or Gantrez copolymer increased the biofilm inhibitory activity of triclosan. This observation is supported by previous studies ${ }^{13,15}$ reporting that the addition of the copolymer gantrez may potentiate the activity of triclosan in vitro. An invitro study on biofilm formation in an experimental biofilm model observed that a mouthwash containing triclosan/gantrez provided a $31 \%$ reduction in biofilm formation when compared to a placebo solution. ${ }^{19}$

Thus, the purpose of this study was to evaluate the antimicrobial efficiency of a mouthwash containing an association of Triclosan/Gantrez and sodium bicarbonate.

\section{Material and Methods}

Volunteers were selected among patients seeking dental care at the Periodontics undergraduate clinic, School of Dentistry of Araraquara, São Paulo State University (UNESP). The protocol was approved by the Research Ethics Committee of that school, and the volunteers that agreed to participate signed an informed consent term after being informed about the nature and purpose of the study.

The inclusion criteria were the following: presence of at least 20 natural teeth; not currently under orthodontic treatment; absence of either fixed or removable prostheses; non-smokers; without any relevant medical alterations, including diabetes, cardiovascular or allergic alterations; no history of therapy with antibiotic, anti-inflammatory or corticosteroid drugs in the previous 2 months.

In order to have microbial samples representative of health- and disease-associated conditions, the 20 volunteers selected included 10 periodontally healthy individuals (less than $10 \%$ of the sites with bleeding of gingival margin, plus a maximum of 2 sites with probing depth $>6.0 \mathrm{~mm}$ or attachment level $>5.0 \mathrm{~mm}$ ); and 10 individuals presenting gingivitis (bleeding of gingival margin in at least $10 \%$ of the sites), but also no more than 2 sites with probing depth $>6.0 \mathrm{~mm}$ or attachment level $>5.0 \mathrm{~mm} .^{5}$

These 20 individuals of both genders, including nine males and eleven females, with at least 20 natural teeth and a mean age of $20 \pm 3.2$ years, showing $24 \pm 11.39 \%$ of visible plaque and $18.85 \pm 12.41 \%$ of gingival index, were submitted to a collection of approximately $3 \mathrm{ml}$ of unstimulated saliva. Streptococcus of the mutans group and Gram-positive filiform bacilli were grown from those samples. Standard strains of bacterial culture from international collections including Actinomyces viscosus, Bacillus subtilis, Streptococcus mutans, Escherichia coli and Pseudomonas aeruginosa were also used alongside those grown from the volunteers' saliva samples. The strains were numbered as follows:

1. Bacillus subtilis $(\mathrm{G}+)$ - standard strain 6633 ; 
2. Actinomyces viscosus $(\mathrm{G}+)$ - standard strain 19246;

3. Streptococcus of the mutans group - patient 13 $(\mathrm{G}+)$;

4. Gram-negative filiform bacillus - patient $14(\mathrm{G}-)$;

5. Escherichia coli (G-) - standard strain 25922;

6. Streptococcus of the mutans group - patient 12 (G+);

7. Streptococcus of the mutans group - patient 09 $(\mathrm{G}+)$;

8. Streptococcus of the mutans group - patient 10 $(\mathrm{G}+)$.

\section{Preparation of samples}

Bacterial samples were put in a sterile vial containing $1 \mathrm{ml}$ of defibrinated blood and then stored frozen at $-18^{\circ} \mathrm{C}$. To restart the cultures, the samples were thawed and aliquots of $0.1 \mathrm{ml}$ were inoculated in Brain-Heart Infusion medium (DIFCO Laboratories Incorporated, Detroit, MI, USA) and incubated at $37^{\circ} \mathrm{C}$ for up to 24 hours. To confirm the purity of the cultures, aliquots were plated in Brain-Heart Infusion Agar under the same conditions.

Bacterial cultures were plated in the Brain-Heart Infusion broth for 24 hours at a temperature of $37^{\circ} \mathrm{C}$. Purity of growth was checked by performing Gram staining on some culture smears and examining them under an optical microscope (Carl Zeiss ICS/KF2, Oberkachen, Germany). The inoculum prepared was always used within 15 minutes in order to maintain microbial viability.

\section{Assessment of the antimicrobial activity of the solutions}

A sensitivity test was carried out according to the agar dilution method described by Sutter et al. ${ }^{17}$ (1979) and by the National Committee for Clinical Laboratory Standards ${ }^{8}$ (1985). Serial dilutions of the different mouthwashes were prepared in artificial saliva (School of Pharmaceutical Sciences of Araraquara, São Paulo State University - UNESP). The solution tested was a mouthwash containing an association of Triclosan/Gantrez and sodium bicarbonate (Kolynos Ah!, Kolynos do Brazil Ind. Com. Ltda., São Paulo, SP, Brazil). The positive control was a $0.12 \%$ Chlorhexidine solution (Periogard,
Colgate-Palmolive Ind. Com. Ltda., São Paulo, SP, Brazil), while the negative control was a placebo (with no mouthwash dilution added).

After that, $10 \mu \mathrm{l}$ of the bacterial inoculum was seeded with a disposable sterile loop onto BrainHeart Infusion Agar plates prepared with dilutions from 1:10 to 1:5120 (v/v) of each mouthwash. The plates were incubated in microaerophilia (pot with candle) at $37^{\circ} \mathrm{C}$ for 48 hours. After 24 and 48 hours of incubation, colony formation was checked by visual inspection.

The dilution was considered effective only when there was no growth of microorganisms on the plate. Sensitivity tests were carried out in triplicate for each dilution and microbial strain tested. The deal was to determine the Minimal Inhibiting Concentration (MIC) of each mouthwash. ${ }^{2}$ The letters "A", "B" and "C" on the headers of the columns of Table 1 represent the experiments performed for each dilution of each mouthwash, according to all bacterial strains used. The results are presented in qualitative form only.

\section{Results}

Standardization of the methods and selection of the microbial species to be used were based on pilot experiments using the same experimental protocol described under 'Material and Methods'. The bacterial strains used were Gram-negative filiform bacilli and Streptococcus of the mutans group, grown from samples of saliva obtained from volunteers with clinically healthy periodontium and also from volunteers with marginal gingivitis. Besides these samples, standard strains from international collection of bacterial cultures were used, including $A c$ tinomyces viscosus, Streptococcus mutans, Bacillus subtilis and Escherichia coli.

The data were tabulated according to the presence or absence of growth of each bacterial strain in the different mouthwash dilutions assessed. Since none of the mouthwashes showed antimicrobial activity in dilutions higher than 1:80, the highest dilution used for the sensitivity test was 1:160.

According to Table 1, the placebo solution (negative control) did not inhibit growth of any bacterial strain used. 
Table 1 - Antimicrobial activity of the tested solutions, according to dilution (1:10, 1:20, 1:40, 1:80, 1:160) and bacterial strain (1 through 8 ) tested.

\begin{tabular}{|c|c|c|c|c|c|c|c|c|c|c|c|c|c|c|c|c|c|c|}
\hline \multirow{3}{*}{$\begin{array}{l}\stackrel{n}{\frac{c}{0}} \\
\frac{\bar{\nu}}{\omega}\end{array}$} & \multirow{2}{*}{\multicolumn{3}{|c|}{ Control }} & \multicolumn{15}{|c|}{ Experimental Mouthwash } \\
\hline & & & & \multicolumn{3}{|c|}{10} & \multicolumn{3}{|c|}{20} & \multicolumn{3}{|c|}{40} & \multicolumn{3}{|c|}{80} & \multicolumn{3}{|c|}{160} \\
\hline & A & B & C & A & B & C & A & B & C & A & B & C & A & B & C & A & B & C \\
\hline 1 & + & + & + & - & - & - & - & - & - & + & + & + & + & + & + & + & + & + \\
\hline 2 & + & + & + & - & - & - & - & - & - & + & + & + & + & + & + & + & + & + \\
\hline 3 & + & + & + & + & + & + & + & + & + & + & + & + & + & + & + & + & + & + \\
\hline 4 & + & + & + & + & + & + & + & + & + & + & + & + & + & + & + & + & + & + \\
\hline 5 & + & + & + & - & - & - & - & - & - & + & + & + & + & + & + & + & + & + \\
\hline 6 & + & + & + & - & - & - & - & - & - & + & + & + & + & + & + & + & + & + \\
\hline 7 & + & + & + & - & - & - & - & - & - & + & + & + & + & + & + & + & + & + \\
\hline 8 & + & + & + & - & - & - & - & - & - & + & + & + & + & + & + & + & + & + \\
\hline & \multirow{2}{*}{\multicolumn{3}{|c|}{ Control }} & \multicolumn{15}{|c|}{$0.12 \%$ Chlorhexidine Solution } \\
\hline & & & & \multicolumn{3}{|c|}{10} & \multicolumn{3}{|c|}{20} & \multicolumn{3}{|c|}{40} & \multicolumn{3}{|c|}{80} & \multicolumn{3}{|c|}{160} \\
\hline & A & B & C & A & B & C & A & B & C & A & B & C & A & B & C & A & B & C \\
\hline 1 & + & + & + & - & - & - & - & - & - & - & - & - & - & - & - & + & + & + \\
\hline 2 & + & + & + & + & + & + & + & + & + & + & + & + & + & + & + & + & + & + \\
\hline 3 & + & + & + & - & - & - & - & - & - & - & - & - & - & - & - & + & + & + \\
\hline 4 & + & + & + & + & + & + & + & + & + & + & + & + & + & + & + & + & + & + \\
\hline 5 & + & + & + & - & - & - & - & - & - & - & - & - & - & - & - & + & + & + \\
\hline 6 & + & + & + & - & - & - & - & - & - & - & - & - & - & - & - & + & + & + \\
\hline 7 & + & + & + & - & - & - & - & - & - & - & - & - & - & - & - & + & + & + \\
\hline 8 & + & + & + & - & - & - & - & - & - & - & - & - & - & - & - & + & + & + \\
\hline & \multirow{2}{*}{\multicolumn{3}{|c|}{ Control }} & \multicolumn{15}{|c|}{ Placebo Solution } \\
\hline & & & & \multicolumn{3}{|c|}{10} & \multicolumn{3}{|c|}{20} & \multicolumn{3}{|c|}{40} & \multicolumn{3}{|c|}{80} & & 160 & \\
\hline & A & B & C & A & B & C & A & B & C & A & B & C & A & B & C & A & B & C \\
\hline 1 & + & + & + & + & + & + & + & + & + & + & + & + & + & + & + & + & + & + \\
\hline 2 & + & + & + & + & + & + & + & + & + & + & + & + & + & + & + & + & + & + \\
\hline 3 & + & + & + & + & + & + & + & + & + & + & + & + & + & + & + & + & + & + \\
\hline 4 & + & + & + & + & + & + & + & + & + & + & + & + & + & + & + & + & + & + \\
\hline 5 & + & + & + & + & + & + & + & + & + & + & + & + & + & + & + & + & + & + \\
\hline 6 & + & + & + & + & + & + & + & + & + & + & + & + & + & + & + & + & + & + \\
\hline 7 & + & + & + & + & + & + & + & + & + & + & + & + & + & + & + & + & + & + \\
\hline 8 & + & + & + & + & + & + & + & + & + & + & + & + & + & + & + & + & + & + \\
\hline
\end{tabular}

The test mouthwash (containing Triclosan/Gantrez and sodium bicarbonate) inhibited the growth of bacterial strain numbers $1,2,5,6,7$ and 8 . The inhibitory dilution of the test solution for all these 6 strains was 1:20 (Table 1).

The $0.12 \%$ Chlorhexidine solution used as positive control also inhibited 6 bacterial strains, including 5 that were inhibited by the test mouth- wash (strains 1, 5, 6, 7 and 8) plus strain number 3 (instead of strain number 2 , inhibited by the test mouthwash). The inhibitory dilution for the positive control was 1:80.

\section{Discussion}

The data were tabulated according to the presence (positive sign on the table) or absence (negative sign on the table) of growth of each bacterial strain in the different mouthwash dilutions assessed. Since none of the mouthwashes showed antimicrobial activity in dilutions higher than 1:80 in the pilot experiment, the highest dilution used for the sensitivity test was 1:160.

The placebo solution (negative control) did not inhibit growth of any bacterial strain used.

The results indicated that the mouthwash solution tested featured a MIC (Minimal Inhibiting Concentration) $)^{2}$ of 1:20 against some standardstrains of bacterial culture from international collection used, including Actinomyces viscosus, $\mathrm{Ba}$ cillus subtilis and Escherichia coli. Moreover, this mouthwash presented efficiency against some strains isolated from the patients' saliva (Streptococcus of the mutans group - patient 12, Streptococcus of the mutans group - patient 09, and Streptococcus of the mutans group - patient 10), but it was not efficient against strains of Streptococcus of the mutans group isolated from the saliva of patient 13 , nor against filiform microorganisms (G-).

The MIC of the positive control mouthwash solution $(0.12 \%$ chlorhexidine) was 1:80 against 5 of the same microorganisms killed by the test mouthwash (numbers 1, 5, 6, 7 and 8). However, it did not inhibit the growth of a standard-strain of $A c$ tinomyces viscosus (number 2), which is a microorganism present in dental biofilm associated with clinical periodontal health. Both test and positive control mouthwash solutions did not inhibit growth of Gram-negative filiform bacilli isolated from the saliva of different patients. ${ }^{14}$

In the present study, antimicrobial activity was assessed by the agar method using serial dilutions of the tested mouthwashes. The agar method is considered a standardized and reliable technique, allowing the simultaneous evaluation of many substances 
using a large number of bacterial strains. Furthermore, this method involves a direct contact of the tested substances with the microbial cultures, which is important for the evaluation of mouthwash solutions. ${ }^{18}$

There are, however, other methods such as the disc diffusion method, which is also commonly used in this type of study, where the diameter of an inhibition halo of bacterial growth is considered to be directly proportional to the antimicrobial activity of the test solution. The diameter of the halo, however, can be influenced by the thickness and composition of the culture, by the concentration of the antimicrobial agent in the paper disc and by the degree of diffusion of the tested substances, which can be affected by the composition of the mouthwashes and dentifrices. ${ }^{16}$

Chlorhexidine-based formulas are currently the golden standard for antimicrobial mouthwashes, with abundant evidence supporting its effectiveness and safety. ${ }^{4}$ Relatively recent information on the literature regarding triclosan ${ }^{6}$, however, has generated interest based not only on its antimicrobial and anti-inflammatory activity, but especially because of the absence of undesirable side effects.

It is important to bear in mind that an experiment conducted in vitro has limitations, as it is considered a static system compared to in vivo tests, which may reflect the influence of various dynamic factors like systemic conditions, salivary flow, diet and dental anatomy. ${ }^{1}$ Nevertheless, it might be considered that if the antimicrobial agent does not have activity in vitro it most likely will not work in vivo.

\section{References}

1. Castro SL, Mardegan MAS, Bandeira MFCL, Pizzolitto AC, Fontana UF. Avaliação in vitro da sensibilidade de microrganismos a anti-sépticos bucais. JBE. 2000;2(1):65-71.

2. Gaetti-Jardim Jr E, Pedrini D, D’Antonio GM. Bactérias anaeróbias isoladas de canais radiculares de dentes desvitalizados e refratários ao tratamento endodôntico. Estudo da suscetibilidade aos antimicrobianos. Rev Odontol UNESP. 1996;25(2):299307.

3. Guggenheim B, Giertsen E, Schüpbach P. Validation of an in vitro Biofilm Model of Supragingival Plaque. J Dent Res. 2001;80(1):363-70.
In this sense, assessments of antimicrobial activity conducted using monocultures in vitro enable a direct contact between the bacterial colonies and the chemical substances tested for a period of 24 to 48 hours (time usually demanded for incubation), ${ }^{3}$ whereas in experiments conducted in vivo there is a greater number of microbial species, including indigenous and even "protective" bacterial species (those species associated with clinical health) which colonize dental biofilm, thus reducing the accuracy of the antimicrobial testing. One way of circumventing the limitations of in vitro studies evaluating the antimicrobial activity of mouthwashes against microorganisms of the dental biofilm is to make reference to clinical studies assessing their efficacy.

\section{Conclusion}

The present study demonstrated an intermediate level of efficacy of a solution containing Triclosan/ Gantrez and sodium bicarbonate against some microbial species found in the oral microbiota, as compared to a placebo solution (negative control) and to a $0.12 \%$ Chlorhexidine solution (positive control).

\section{Acknowledgements}

The present study was supported by Grants from FUNDUNESP (Proc. $n^{\circ} 171 / 99$ ) and FAPESP (Proc. $\mathrm{n}^{\mathrm{o}}$ 99/12172-1). We also wish to thank the technicians of the Clinical Microbiology Laboratory, and Maria do Carmo Dória Martins from the Department of Clinical Analysis, School of Pharmaceutical Sciences of Araraquara, São Paulo State University (UNESP).

4. Jenkins S, Addy M, Newcombe RG. A comparison of cetylpiridinium chloride, triclosan and chlorhexidine mouthrinse formulations for effects on plaque regrowth. J Clin Periodontol. 1994;21(6):441-4.

5. Löe H, Silness J. Periodontal disease in pregnancy. I. Prevalence and severity. Acta Odontol Scand. 1963;21:533-51.

6. Moran J, Addy M, Newcombe RG, Marlow I. A study to assess the plaque inhibitory activity of a new triclosan mouthrinse formulation. J Clin Periodontol. 2000;27(11):806-9.

7. Nabi N, Mukerjee C, Schmid R, Gaffar A. In vitro and in vivo studies on triclosan/PVM/MA copolymer/ $\mathrm{NaF}$ combination 
as an anti-plaque agent. Am J Dent. 1989;2 Spec $\mathrm{N}^{\circ}: 197-$ 206.

8. National Committee for Clinical Laboratory Standards (NCCLS). Reference agar dilution procedure for antimicrobial susceptibility testing of anaerobic bacteria. Approved standard. M-11 A. Villanova, PA: NCCLS; 1985.

9. Nogueira-Filho GR, Duarte PM, Toledo S, Tabchoury COM, Cury JA. Effect of triclosan dentifrices on mouth volatile sulphur compounds and dental plaque trypsin-like activity during experimental gingivitis development. J Clin Periodontol. 2002;29(12):1059-64.

10. Nogueira-Filho GR, Toledo S, Cury JA. Effect of 3 dentifrices containing triclosan and various additives. An experimental gingivitis study. J Clin Periodontol 2000. 2000;27(7):494-8.

11. Pires JR, Rossa Jr C, Pizzolitto AC, Cancian DCJ, Massone ACB. Eficiência de uma solução para bochecho contendo Triclosan/Gantrez e bicarbonato de sódio associado à escovação na redução de placa e gengivite. JBC. 2003;7(38):132-6.

12. Rodrigues LG, Zawadzki PT, Calvete E. O efeito do Plax na formação de nova placa bacteriana. Rev Periodontia. 1999;8(2):3944.

13. Rustogi KN, Petrone DM, Singh SM, Volpe AR, Tavss E. Clinical study of a pre-brush rinse and a triclosan/copolymer mouthrinse: effect on plaque formation. Am J Dent. 1990;3 Spec $\mathrm{N}^{\circ}:$ S67-9.

14. Schiff TG. The effect of a dentifrice containing soluble pyrophosphate and sodium fluoride on calculus deposits: A sixmonth clinical study. Clin Prev Dent. 1987;9(2):13-6.

15. Singh SM, Rustogi KN, Volpe AR, Petrone DM, Robinson RS. Effect of a mouthrinse containing triclosan and a copolymer on plaque formation in a normal oral hygiene regimen. Am J Dent. 1991;4(2):102.

16. Sperança PA, Barbosa AFB. Estudo comparativo da atividade antimicrobiana de produtos químicos pré e pós-escovação, indicados no controle de placa dental. Estudo in vitro. Rev Periodontologia. 1993;2(7):39-44.

17. Sutter VL, Barry AL, Wilkins TD, Zabransky RJ. Collaborative evaluation of a proposed reference dilution method of susceptibility testing of anaerobic bacteria. Antimicrob Agents Chemother. 1979;16(4):495-502.

18. Washington JA, Woods GL. Antibacterial susceptibility Tests: Dilution and Disk Diffusion Methods. Manual of Clinical Microbiology. $6^{\text {th }}$ ed. St. Louis: Mosby; 1995.

19. Williams M, Herles S, Olsen S, Afflitto J, Gaffar A. In vitro antiplaque effects of a triclosan/copolymer mouthrinse. Am J Dent. 1990;3 Spec Nº: S53-6. 